\title{
Erratum to: A novel mutation (Cys308Phe) of the LDL receptor gene in families from the South-Eastern part of Poland
}

\author{
Małgorzata Walus-Miarka ${ }^{1} \cdot$ Marek Sanak $^{2} \cdot$ Barbara Idzior-Waluś $^{1}$ \\ Przemysław Miarka ${ }^{3}$ Przemysław Witek ${ }^{1}$ Maciej T. Małecki ${ }^{1}$. \\ Danuta Czarnecka ${ }^{4}$
}

Published online: 28 April 2015

(C) Springer Science+Business Media Dordrecht 2015

\section{Erratum to: Mol Biol Rep (2012) 39:5181-5186 \\ DOI 10.1007/s11033-011-1314-0}

Due to an oversight, the authors omitted mention of the fact that their project received financial support from National Science Centre; number N N404 070933 based on decision number 0709/B/P01/2007/33. They regret the omission.

The online version of the original article can be found under doi:10.1007/s11033-011-1314-0.

Małgorzata Walus-Miarka

mmwalus@wp.pl

1 Department of Metabolic Diseases, Jagiellonian University, Medical School, Kopernika 15, 31-501 Kraków, Poland

2 II Department of Internal Medicine, Jagiellonian University, Medical School, Kraków, Poland

3 Department of Nephrology, Jagiellonian University, Medical School, Kraków, Poland

4 I Department of Cardiology, Jagiellonian University, Medical School, Kraków, Poland 